\title{
Effects of Deficit Irrigation and Phosphorus Levels on Growth, Yield, Yield Components and Water use Efficiency of Mung Bean (Vigna radiata (1.) Wilczek) at Alage, Central Rift Valley of Ethiopia
}

\author{
Arebu Hussen ${ }^{1 *}$, Walelign Worku² and Moltot Zewdie ${ }^{3}$ \\ ${ }^{1}$ Department of Plant Science, Alage ATVET College, Ethiopia \\ ${ }^{2}$ College of Agriculture, Hawassa University, Ethiopia \\ ${ }^{3}$ Institute of Technology, Hawassa University, Ethiopia
}

Submission: March 13, 2019; Published: May 13, 2019

"Corresponding author: Arebu Hussen, Department of Plant Science, Alage ATVET College, P. O. Box 77, Alage, Ethiopia

\begin{abstract}
Mung bean (Vigna radiata L. Wilczek) is one of the most important short-season grain legumes and has good content of protein. However, due to the recent introduction of mung bean crop, appropriate recommendations of fertilizer and optimum crop water requirement are lacking for the farmers in Ethiopia. This study investigates the effects of water deficit and levels of phosphorus on growth, yield, yield components, water use efficiency, and economic feasibility of mung bean crop production. The twelve treatments- three irrigation levels $(50 \%, 75 \%$ and $100 \%$ of crop water requirements (ETc) $)$ and four rates of phosphorus $\left(0,23,46\right.$ and $69 \mathrm{~kg} \mathrm{P}_{2} \mathrm{O}_{5}$ ha $\left.\mathrm{a}^{-1}\right)$ were laid out in a split-plot design and irrigation was assigned to main plots and phosphorus to subplots and replicated thrice. The highest grain yield $\left(1.124 \mathrm{t} \mathrm{ha}^{-1}\right)$ was obtained from the application of irrigation water at $100 \%$ ETc which was statistically at par with that from $75 \%$ ETc irrigation level. The highest grain yield $\left(1.072 \mathrm{t}\right.$ ha $\left.{ }^{-1}\right)$ was produced by application of $46 \mathrm{~kg} \mathrm{P}_{2} \mathrm{O}_{5}$ ha $^{-1}$. The partial budget analysis showed that both $75 \%$ and $100 \% \mathrm{ETc}$, and $46 \mathrm{~kg}_{2} \mathrm{O}_{5}$ ha ${ }^{-1}$ gave marginal rate of returns above the minimum acceptable values. Therefore, it can be concluded that, for the intention of sustainable water resource use and increase water use efficiency application of $75 \%$ ETc irrigation and $46 \mathrm{~kg} \mathrm{P}_{2} \mathrm{O}_{5} \mathrm{ha}^{-1}$ phosphorus may possibly be recommended for better mung bean production at the study area and areas with similar agroecology.
\end{abstract}

Keywords: Mung bean; Grain yield; Deficit irrigation; Phosphorus; Water use efficiency

\section{Introduction}

Mung bean (Vigna radiata L.) is one of the most important short-season grain legumes that belongs to the family Fabaceae, and subgenus Ceratotropis in the genus Vigna. The crop is characterized by fast growth under warm conditions, low water requirement, and excellent soil fertility enhancement via nitrogen fixation [1]. Among pulses, mung bean is noted for its protein and lysine-rich grain, which supplements cereal-based diets [2]. The crop is utilized in several ways; seeds, sprouts and young pods are all consumed and provide a rich source of amino acids, vitamins and minerals [3]. It is known by its nutritive value and digestibility and contains $28 \%$ protein, $1.3 \%$ fat, $60.4 \%$ carbohydrates and a reasonable number of vitamins and essential micronutrients $[4,5]$.

According to Asfaw et al. [6], in Ethiopia mung bean is mostly grown by smallholder farmers under drier marginal environmental conditions and the production capacity is lower than other pulse crops. Mung bean is mostly produced in Amhara regional state particularly in some areas of North Shewa and South Wollo. It is currently being cultivated in the Oromia, Tigray, Benishangul Gumuz, and Southern Nation and Nationalities Peoples Regional State. According to CSA [7], in the years of 2015/16 and 2016/17, the production area of Ethiopia increased from 27,085 to 37,774 hectares and production was improved from $27,158.98$ tons to $42,915.55$ tons with $39.46 \%$ and $58.02 \%$ changes, respectively. In the same way, the area under mung bean production in the country is increasing from time to time mainly due to its high profitability per unit area and the increases in small-scale irrigation areas during off-season. The crop is produced both under rain-fed in the rainy season and under irrigation in the off season. Rehman et al. [8] reported that mung bean is grown in several types of cultivation systems, including sole cropping, intercropping, multiple cropping and relay cropping, where it is planted after cereals us- 
ing the residual moisture. It has good potential for crop rotation system under dry farmland cultivation areas as well as irrigated condition areas [9].

Ethiopian farmers mostly depend on rain-fed agriculture. Because of the erratic nature of rainfall and frequent drought, there are frequent crop failures which have resulted in a chronic food shortage [10]. Montazar [11] stated that to produce more food with less water would require increasing water productivity through adaptation of genotypes and development of new water management technologies in arid and semi-arid regions for better utilization of the limited water resource. Under conditions of water stress and drought, deficit irrigation can lead to greater water use efficiency by maximizing yield per unit of water used. The yield response can vary depending on crop sensitivity at that growth stage when water deficit occurs during a specific crop development period [12]. Therefore, timing the water deficit appropriately is a tool for scheduling irrigation for efficient utilization of irrigation water. Mung bean plants under water stress attained maturity earlier than the well-watered treatment but number of floral buds and pods per plant were affected [13].

Growth, development, and yield of mung bean are greatly affected by nutrient management. Like other legumes, mung bean requires nitrogen, phosphorus, potassium, calcium, magnesium, and sulfur for growth and development [14]. Phosphorus (P) is among the most needed elements for crop production in most tropical soils, which tends to be P deficient [15]. Phosphorus deficiencies primarily result from either inherent low level of soil P or depletion through cultivation. Phosphorus has a vital role in plant nutrition by enhancing nitrogen absorption, influencing pods and seeds formation in legumes and contributing significantly to plant energy processes [16]. Phosphorus applications increase the growth, yield and yield components of mung bean, and improve the quality of its product [17]. As Iqbal et al. [18] reported the application of phosphorus increases plant dry matter, seed yield and P uptake of mung bean. Phosphorus application along with micronutrients can increase the biological activity, which can result in improvements to plant height, number of nodules per plant, number of pods per plant and enhanced straw quality [19]. Singh et al. [20] reported that growth characters such as branches per plant, leaves per plant, leaf area index and plant dry matter accumulation, and yield attributes like pod length, pods per plant, grains per pod and 1000 grain weight of mung beans were significantly affected by different levels of irrigation and phosphorus. The uptake of phosphorus in the plants increased with increased irrigation levels. However, water use efficiency decreased with increasing levels of irrigation.

As Sisay et al. [21] noted that mung bean is moderately sensitive to drought and has a potential to grow in Ethiopia arid and semiarid regions. Amount and frequency of irrigation and fertilization influence yield and quality of mung bean. However, due to the recent introduction of the mung bean crop, appropriate recommendations are lacking for the farmers throughout Ethiopia, particularly in the study area (Alage), which are vital to enhance productivity and expansion of the crop. In view of the existing problem, this study was conducted to investigate the effects of water deficit and levels of phosphorus on growth, yield, yield components and water use efficiency of mung bean under Alage condition. The specific objectives of this study were to determine effects of deficit irrigation and phosphorus rates on growth, yield and yield component of mung bean, to assess the water use efficiency under deficit irrigation regimes and to evaluate comparative economic benefits among the various deficit irrigations and $\mathrm{P}$ rates.

\section{Materials and Methods}

\section{Description of the study area}

Table 1: Summary of climatic data (2007-2016) of Alage used for determination of ETo.

\begin{tabular}{|c|c|c|c|c|c|c|c|}
\hline Month & Min.To $\left({ }^{\circ} \mathrm{C}\right)$ & Max.To $\left({ }^{\circ} \mathrm{C}\right)$ & Humidity (\%) & Wind (km/day) & Sun Hours & $\operatorname{Rad}\left(M J / m^{2} /\right.$ day $)$ & ETo (mm/day) \\
\hline January & 11 & 28.7 & 58 & 77 & 8.2 & 19.9 & 3.87 \\
\hline February & 12 & 29.3 & 56 & 79 & 8.3 & 21.2 & 4.22 \\
\hline March & 12.2 & 31 & 60 & 78 & 8.8 & 23 & 4.68 \\
\hline April & 12.5 & 30.5 & 63 & 80 & 8.2 & 22.1 & 4.59 \\
\hline May & 12.1 & 28.6 & 74 & 81 & 7.8 & 20.9 & 4.16 \\
\hline June & 12 & 27.5 & 76 & 97 & 6.8 & 19 & 3.8 \\
\hline July & 11.8 & 26.5 & 78 & 54 & 5.5 & 17.2 & 3.35 \\
\hline August & 11.6 & 25.5 & 75 & 38 & 5.7 & 17.9 & 3.35 \\
\hline September & 11.9 & 26.7 & 75 & 70 & 5.6 & 17.9 & 3.53 \\
\hline October & 10.5 & 27.1 & 71 & 71 & 8.4 & 21.5 & 4.01 \\
\hline November & 9.5 & 28.2 & 61 & 87 & 8.9 & 21.1 & 4.03 \\
\hline December & 10.2 & 28.4 & 55 & 86 & 8.5 & 19.9 & 3.87 \\
\hline
\end{tabular}

Source: Alage Meteorological station: ETo calculated using CROPWAT. 
The study was conducted at Alage Agricultural Technical and Vocational Education Training College in central rift valley of Ethiopia during the $2017 / 2018$ dry season. The college is located $217 \mathrm{~km}$ south of Addis Ababa city and $32 \mathrm{~km}$ west of Bulbula town in the vicinity of Rift valley lakes (Lake Abidjata and Shalla). It is situated at $7^{\circ} 65^{\prime} \mathrm{N}$ latitude and $38^{\circ} 56^{\prime}$ E longitudes and at an altitude of 1600 meters above sea level. The area is characterized by Table 2: Physico-chemical characteristics of the experimental soil. a bimodal rainfall pattern. The mean annual rainfall is $800 \mathrm{~mm}$, the annual mean minimum and maximum temperatures are $11^{\circ} \mathrm{C}$ and $29^{\circ} \mathrm{C}$, respectively (Table 1 ). The soil had silty clay loam, slightly alkaline $(\mathrm{pH}=7.8)$, medium in total nitrogen, low in phosphorus, high in organic carbon, medium in organic matter and high in cations exchange capacity (CEC) (Table 2).

\begin{tabular}{|c|c|c|c|}
\hline S.No. & Soil Properties & Values & Standard Rating \\
\hline 1 & $\mathrm{pH}$ & 7.8 & $7.2-8.2$ (slightly alkaline) \\
\hline 2 & Organic Carbon (\%) & 1.82 & 2.5 (high) \\
\hline 3 & Organic Matter (\%) & 3.14 & $0.16-0.25$ (medium) \\
\hline 4 & Total Nitrogen (\%) & 0.16 & $<5$ (low) \\
\hline 5 & Carbon: Nitrogen & 11.4 & $>25$ (high) \\
\hline 6 & Avail. Phosphorus (mg/kg soil) & 4.2 & $1-2$ (low salinity) \\
\hline 7 & Cation Exchange Capacity (cmol (+) kg-1) & 28.85 & 1.24 \\
\hline 8 & Electric Conductivity (ds/m) & 19 & \\
\hline 9 & Sand (\%) & 56 & 25 \\
\hline 11 & Silt (\%) & Silty clay loam & \\
\hline 12 & Clay (\%) & Textural Class & \\
\hline
\end{tabular}

\section{Experimental design and treatments}

Table 3: Description of Factorial Combination of Irrigation and Phosphorus Treatments.

\begin{tabular}{|c|c|c|c|c|}
\hline \multirow{2}{*}{$\begin{array}{c}\text { Irrigation Levels (\% } \\
\text { ETc) }\end{array}$} & \multicolumn{4}{|c|}{ Phosphorus $\left(\mathbf{P}_{\mathbf{2}} \mathbf{0}_{\mathbf{5}}\right)$ Fertilizer Rates $(\mathrm{kg} / \mathbf{h a})$} \\
\cline { 2 - 5 } & 0 & 23 & 46 & 69 \\
\hline 50 & $0+50$ & $23+50$ & $46+50$ & $69+50$ \\
\hline 75 & $0+75$ & $23+75$ & $46+75$ & $69+75$ \\
\hline 100 & $0+100$ & $23+100$ & $46+100$ & $69+100$ \\
\hline
\end{tabular}

The experiment consisted of three irrigation levels [50\%, 75\% and $100 \%$ of crop water requirement (ETc)] and four phosphorus rates $\left(0,23,46\right.$ and $69 \mathrm{~kg} \mathrm{P}_{2} \mathrm{O}_{5}$ ha $\left.^{-1}\right)$ which were laid out in split plot design in factorial arrangement using irrigation levels as main plot and phosphorus rates as sub-plot and replicated three times. Each treatment combination was assigned randomly to the experimental units within a block (Table 3 ).

Full irrigation (100\% ETc) implies the amount of irrigation water applied in accordance with the computed crop water requirement with the aid of CROPWAT model software program version 8.0. CROPWAT is meant as a practical tool to carry out standard calculations for reference evapotranspiration, crop water requirements and irrigation water requirements. The mung bean seed was sown on the plots with spacing of $10 \mathrm{~cm}$ between plants and $30 \mathrm{~cm}$ between rows. Each experimental plot had $2 \mathrm{~m}$ length and $2.4 \mathrm{~m}$ width having an area of $4.8 \mathrm{~m}^{2}$, with 8 rows (lines) with 20 plants per row (line) and had a total of 160 plants per plot. The distance between subplots, main plots and blocks were $1 \mathrm{~m}, 1.5 \mathrm{~m}$ and $1.5 \mathrm{~m}$, respectively.
Table 4: Mung bean crop parameters adopted from FAO irrigation and drainage Paper No. 56 used in CROPWAT model.

\begin{tabular}{|c|c|c|c|c|c|}
\hline Growth stages & Initial & $\begin{array}{c}\text { Devel- } \\
\text { opment }\end{array}$ & Mid & Late & Total \\
\hline Rooting Depth (m) & 0.1 & >> & 0.6 & 0.6 & \\
\hline $\begin{array}{c}\text { Critical Depletion Coef- } \\
\text { ficient }\end{array}$ & 0.45 & 0.45 & 0.45 & 0.45 & \\
\hline Crop Coefficient (kc) & 0.4 & $>>>$ & 1.05 & 0.35 & \\
\hline Number of Days & 15 & 25 & 30 & 25 & 95 \\
\hline $\begin{array}{c}\text { Yield Response Factor } \\
\text { (ky) }\end{array}$ & 0.2 & 1.1 & 0.75 & 0.2 & 1.15 \\
\hline $\begin{array}{c}\text { Max. Crop Height (op- } \\
\text { tional) }\end{array}$ & & & 0.4 & & \\
\hline
\end{tabular}

\section{Source: Allen et al. [23]}

Note: ">>> indicates the value is found between the right and the left column.

First, the land was selected, then ploughed and leveled by tractors and was made ready for sowing after which the seed of Rasa variety was sown by dibbling methods. The calculated phosphorus fertilizer in the form of TSP was applied in band application method near to mung bean seed at the time of sowing. The recommended $18 \mathrm{~kg} /$ ha nitrogen fertilizer was applied in all plots in split application style once at sowing and another was 40 days after planting. Before starting deficit irrigation treatments, full irrigation water (100\% ETC) was applied for one week up to 50\% emergence of seeds to ensure good plant establishment. Then after, the respective irrigation treatments were applied to individual plots according to the treatments designed. Other than the treatments, 
uniform field management, disease, pest and weed control and cultivation were performed to all plots as per the recommendation made for the crops [22].

Irrigation scheduling was done using the CROPWAT model software program of FAO Penman-Monteith method [23] to calculate reference crop evapotranspiration (ETo), crop water require- ment (ETc), crop irrigation requirement and estimate optimum crop water requirement (ETc) on daily time steps and adopting the three days irrigation interval. Crop growth stage, crop coefficient (Kc), root depth, critical depletion coefficient, yield response factor and maximum crop height were taken from FAO irrigation and drainage paper 56 (Table 4).

Table 5: CROPWAT estimations net and gross irrigation (depth of irrigation water) applied to each treatment throughout the growth season.

\begin{tabular}{|c|c|c|c|c|c|c|c|c|}
\hline \multirow{2}{*}{ Date } & \multirow{2}{*}{ Day } & \multirow{2}{*}{ Stage } & \multicolumn{3}{|c|}{ Net Irrigation (mm) } & \multicolumn{3}{|c|}{ Gross Irrigation (mm) } \\
\hline & & & $100 \%$ ETc & $75 \%$ ETc & $50 \%$ ETc & $100 \%$ ETc & $75 \%$ ETc & $50 \%$ ETC \\
\hline 9-Jan & 1 & Init & 13 & $\#$ & $\#$ & 18.5 & $\#$ & $\#$ \\
\hline 12-Jan & 4 & Init & 8.2 & $\#$ & $\#$ & 11.7 & $\#$ & $\#$ \\
\hline 15-Jan & 7 & Init & 8.3 & 6.23 & 4.15 & 11.8 & 8.85 & 5.9 \\
\hline 18-Jan & 10 & Init & 7.6 & 5.7 & 3.8 & 10.8 & 8.1 & 5.4 \\
\hline 21-Jan & 13 & Init & 4.6 & 3.45 & 2.3 & 6.6 & 4.95 & 3.3 \\
\hline 24-Jan & 16 & Dev & 6.9 & 5.18 & 3.45 & 9.9 & 7.43 & 4.95 \\
\hline 27-Jan & 19 & Dev & 11.5 & 8.63 & 5.75 & 16.6 & 12.45 & 8.3 \\
\hline 30-Jan & 22 & Dev & 5.5 & 4.13 & 2.75 & 7.8 & 5.85 & 3.9 \\
\hline 2 -Feb & 25 & Dev & 4.7 & 3.53 & 2.35 & 6.7 & 5.03 & 3.35 \\
\hline 5-Feb & 28 & Dev & 8.2 & 6.15 & 4.1 & 11.7 & 8.78 & 5.85 \\
\hline 8-Feb & 31 & Dev & 7 & 5.25 & 3.5 & 10 & 7.5 & 5 \\
\hline $11-\mathrm{Feb}$ & 34 & Dev & 14.8 & 11.1 & 7.4 & 21.1 & 15.83 & 10.55 \\
\hline $14-\mathrm{Feb}$ & 37 & Dev & 5.5 & 0 & 0 & 10.1 & 6.33 & 2.55 \\
\hline $17-\mathrm{Feb}$ & 40 & Dev & 15.2 & 10.78 & 4.35 & 22.7 & 17.03 & 11.35 \\
\hline $20-\mathrm{Feb}$ & 43 & Mid & 10.6 & 7.2 & 3.8 & 16.4 & 11.55 & 6.7 \\
\hline 23-Feb & 47 & Mid & 13.8 & 10.35 & 6.9 & 19.8 & 14.85 & 9.9 \\
\hline 27-Feb & 50 & Mid & 0.5 & 0 & 0 & 4.6 & 3.7 & 0 \\
\hline 2-Mar & 53 & Mid & 15.1 & 9.46 & 3.3 & 22.4 & 16.8 & 9 \\
\hline 5-Mar & 56 & Mid & 14.3 & 10.73 & 7.15 & 20.4 & 15.3 & 10.2 \\
\hline 8-Mar & 59 & Mid & 15.3 & 11.48 & 7.65 & 22.9 & 17.18 & 11.45 \\
\hline 11-Mar & 62 & Mid & 14.8 & 11.1 & 7.4 & 21.1 & 15.83 & 10.55 \\
\hline 14-Mar & 65 & Mid & 14.8 & 11.1 & 7.4 & 21.1 & 15.83 & 10.55 \\
\hline 17-Mar & 68 & Mid & 14.4 & 10.8 & 7.2 & 20.5 & 15.38 & 10.25 \\
\hline 20-Mar & 71 & Mid & 14.2 & 10.65 & 7.1 & 20.2 & 15.15 & 10.1 \\
\hline 23-Mar & 74 & End & 9.4 & 7.05 & 4.7 & 13.5 & 10.13 & 6.75 \\
\hline 26-Mar & 77 & End & 14.2 & 10.65 & 7.1 & 20.2 & 15.15 & 10.1 \\
\hline 29-Mar & 80 & End & 17.8 & 13.35 & 8.9 & 25.2 & 18.9 & 12.6 \\
\hline 1-Apr & 83 & End & 7.9 & 5.93 & 3.95 & 11.3 & 8.48 & 5.65 \\
\hline 4-Apr & 86 & End & 6.6 & 4.95 & 3.3 & 9.4 & 7.05 & 4.7 \\
\hline 7-Apr & End & End & & & & & & \\
\hline Total & 89 & & 275.2 & 226.13 & 150.95 & 403 & 339.61 & 229.1 \\
\hline
\end{tabular}

\# = the same water applied to all plot; Init = initial growth stage of the crop; Dev = development stage of the crop; Mid = middle stage of the crop and End $=$ End or late stage of the crop.

The amount of irrigation water applied to each treatment was calculated after estimation of crop water requirement by using CROPWAT. The volume of water applied to each plot was then cal-

culated by multiplying the depth of water (gross irrigation) with the area of the plot [24] as:

$$
V=A * D * 1000
$$


Where, $\mathrm{V}=$ Volume of water to be applied (lit), $\mathrm{A}=$ Area of the plot $\left(\mathrm{m}^{2}\right)$ and $\mathrm{D}=$ Depth of application $(\mathrm{m})$

$1000=$ Constant to convert $\mathrm{m}^{3}$ to liter.

The calculated volume of water was measured with a bucket of known volume and applied as per the irrigation treatment to each plot manually.

The minimum $(3.35 \mathrm{~mm} /$ day) and maximum $(4.68 \mathrm{~mm} /$ day) ETO value occurred in the months of August and March respectively. Generally, the evaporative power of the atmosphere was under moderate range (3-5mm/day) [23]. For optimal condition the total water requirement of mung bean in the growing period of 89 days with irrigation efficiency of $70 \%$ was the net irrigation of $275.2 \mathrm{~mm}$, and the gross irrigation of $403 \mathrm{~mm}$ but unexpected $17 \mathrm{~mm}$ amount of rain was rained (Table 5). Therefore, the amount of gross irrigation for non-stressed experimental unit was 1,999 liters with a plot area of $2 \mathrm{~m} \times 2.4 \mathrm{~m}$.

\section{Data Collection and analysis}

Phenology and growth parameters: Plant phenological parameters such as days to $50 \%$ flowering and $95 \%$ physiological maturity were recorded on plot basis from the four central rows. Plant height, number of branches per plant, number of nodules per plant, nodule dry weight and shoot dry matter were recorded on plants basis by selecting five plants randomly from each plot. Pod length and number of pods were recorded from five randomly selected plants per plot. Five pods were randomly taken to determine the average number of seeds per pod. At maturity, whole plants from the four central rows of net plot area $(2 \mathrm{~m} \times 1.2 \mathrm{~m}=$ $2.4 \mathrm{~m}^{2}$ ) were manually harvested, sundried and threshed to calculate hundred seed weight, grain yield, biological yield, harvest index and crop and irrigation water use efficiency.

Partial budget analysis was carried out by using the methodology described in CIMMYT [25]. Some of the concepts used in the partial budget analysis are average grain yield $\mathrm{ha}^{-1}$, adjusted grain yield $\mathrm{ha}^{-1}$, total variable cost (TVC), gross field benefit (GFB), and the net benefit (NB). The following formula was used to estimate the cost and benefits of different treatment combinations:

Gross field benefit $=$ Adjusted yield $\mathrm{x}$ unit price

Adjusted yield $=$ Average yield $-($ Average yield*0.10)

$$
\text { Marginal rate of return }(\%)=\frac{\text { change in net benefit }}{\text { change in total cost }} \times 100
$$

The minimum acceptable rate of return was set $100 \%$.

The collected data was subjected to analysis of variances (ANOVA) using SAS computer software program (version 9.0) and significant treatment means were compared using least significant difference (LSD) at $\mathrm{P}<0.05$ probability level. Correlation among parameters was done using Pearson simple correlation coefficient.

\section{Results and Discussion}

\section{Phenology and growth parameters}

Days to flowering: The obtained result showed that days to $50 \%$ flowering was significantly $(\mathrm{P}<0.001)$ affected by the main effect of irrigation and phosphorus treatments. However, the interaction effect was non-significant. The 100\% ETc had delayed flowering (38 days) while 50\% ETc (33 days) the earliest to days to flowering from emergence (Table 6). The crop that imposed to full irrigation extended days to flowering by an average of 5 days as compared to $50 \%$ deficit irrigation. The result obtained is in line with the findings of Sisay et al. [21] who noted that days to flowering tend to decline under deficit irrigation and increase in optimal irrigation. This might be due to the circumstance of plants under water stress, which tends to complete their life cycle a few days earlier than those under normal or high soil moisture conditions. This enables them to escape unfavorable conditions, thereby ensuring the perpetuation of the species [26].

Table 6: Main effects of irrigation levels and phosphorus rates on days to flowering, days to physiological maturity, plant height, No. of branches plant $^{-1}$ and shoot dry matter.

\begin{tabular}{|c|c|c|c|c|c|}
\hline Treatments & Days to Flowering & Days to Physiological Maturity & Plant Height (cm) & No of Branches Plant ${ }^{-1}$ & Shoot Dry Matter (g) \\
\hline \multicolumn{6}{|c|}{ Irrigation Levels } \\
\hline $50 \%$ ETc & $32.50^{c}$ & $58^{c}$ & $21.01^{\mathrm{b}}$ & $3.82^{\mathrm{b}}$ & $8.77^{\mathrm{c}}$ \\
\hline $75 \%$ ETc & $35.58^{\mathrm{b}}$ & $64^{\mathrm{b}}$ & $26.49^{\mathrm{ab}}$ & $4.76^{\mathrm{b}}$ & $13.85^{\mathrm{b}}$ \\
\hline $100 \%$ ETc & $37.67^{\mathrm{a}}$ & $69^{a}$ & $35.01^{\mathrm{a}}$ & $6.29^{\mathrm{a}}$ & $15.66^{\mathrm{a}}$ \\
\hline $\operatorname{LSD}_{0.05}$ & 1.31 & 1.72 & 9.95 & 1.27 & 1.04 \\
\hline \multicolumn{6}{|c|}{$\mathrm{P}_{2} \mathrm{O}_{5}\left(\mathrm{~kg} \mathrm{ha}^{-1}\right)$} \\
\hline 0 & $36.78^{\mathrm{a}}$ & $66.44^{\mathrm{a}}$ & $22.67^{c}$ & $4.14^{\mathrm{c}}$ & $10.31^{\mathrm{d}}$ \\
\hline 23 & $36.67^{\mathrm{a}}$ & $65.11^{\mathrm{b}}$ & $25.74^{\mathrm{b}}$ & $4.69^{\mathrm{b}}$ & $11.51^{c}$ \\
\hline 46 & $33.56^{b}$ & $61.44^{\mathrm{c}}$ & $31.18^{\mathrm{a}}$ & $5.54^{\mathrm{a}}$ & $15.24^{\mathrm{a}}$ \\
\hline 69 & $34.00^{\mathrm{b}}$ & $61.33^{c}$ & $30.42^{\mathrm{a}}$ & $5.45^{\mathrm{a}}$ & $14.00^{\mathrm{b}}$ \\
\hline $\operatorname{LSD}_{0.05}$ & 0.899 & 1.065 & 2.9 & 0.397 & 1.19 \\
\hline $\mathrm{CV} \%$ & 2.57 & 1.69 & 10.67 & 8.09 & 9.39 \\
\hline
\end{tabular}

LSD = Least significant difference, $C V=$ coefficient of variations. Means followed by the same letter within the column are not significantly different at $\mathrm{P}<0.05$. 
Days to flowering was also significantly delayed by the application of phosphorus at the level of $23 \mathrm{~kg} \mathrm{P}_{2} \mathrm{O}_{5}$ ha $^{-1}$ and control $(0 \mathrm{~kg}$ $\mathrm{P}_{2} \mathrm{O}_{5}$ ha $^{-1}$ ) while shortened by the application of 46 and $69 \mathrm{~kg} \mathrm{P}_{2} \mathrm{O}_{5}$ ha $^{-1}$ (Table 6). Generally, as $\mathrm{P}$ rate increase from 0 to $46 \mathrm{~kg} \mathrm{P}_{2} \mathrm{O}_{5} \mathrm{ha}^{-1}$ the days to flowering were reduced from 37 to 34 . The delay in days to flowering with the reduction in $\mathrm{P}$ supplies has also been reported for mung bean $[27,28]$ and common bean [29].

Days to physiological maturity: Days to physiological maturity were significantly $(\mathrm{P}<0.001)$ influenced by irrigation levels and phosphorus rates. However, the interaction effect was non-significant. The result indicated that the plants treated with $50 \%$ ETc were the earliest to mature (58 days) while 100\% ETc (69 days) the latest to mature (Table 6). The plant that was treated by $100 \%$ ETc on average had a $16 \%$ delay in days to physiological maturity as compared to $50 \%$ ETc. This result is in line with Sisay et al. [21], Thomas et al. [30], and Uddin et al. [31] who reported that mung bean plants under deficit irrigation attained maturity earlier than optimal irrigation.

The effect of $\mathrm{P}$ on days to physiological maturity showed that plants treated with $69 \mathrm{~kg} \mathrm{P}_{2} \mathrm{O}_{5} \mathrm{ha}^{-1}$ were the earliest (61 days) while the latest was treated with $0 \mathrm{~kg} \mathrm{P}_{2} \mathrm{O}_{5}$ ha $^{-1}$ (66 days) to mature. However, there was no significant difference between 46 and $69 \mathrm{~kg}$ $\mathrm{P}_{2} \mathrm{O}_{5}$ ha $^{-1}$ rates (Table 6). This result agrees with those of Dereje et al. [32] and Nkaa et al. [33] who reported that P fertilizer application reduces the days to physiological maturity by monitoring some key enzyme reactions that involve in hastening crop maturity in cowpea and haricot bean. On the contrary, Rama [34] and Singh et al. [20] reported that increasing phosphorus application delayed days to flowering and maturity in mung bean and french bean, respectively.

Plant height: The obtained result showed that only the main effects of irrigation levels and phosphorus rates had significant $(\mathrm{P}<0.001)$ influence on plant height. The effect of irrigation levels indicated that plants treated with $100 \%$ ETc had the tallest plant height $(35 \mathrm{~cm})$ whereas plants treated with $50 \%$ ETc had the shortest plant height $(21 \mathrm{~cm})$ (Table 6). The $50 \%$ ETc reduced mean plant height by about $40 \%$ as compared to the $100 \%$ ETc. The shortest plant height at $50 \%$ ETc might be since under soil moisture stresses the physiological process of the plant like assimilation, photosynthesis and translocation are slowing down, and ultimately decrease the plant height by inhibiting cell division and cell enlargement. This finding agrees with the finding of Sisay et al. [21] who reported that mung bean plants that received the optimal amount of irrigation water throughout the whole growth stages have higher plant height than those under water stress. Similarly, Merkebu [35] also reported that the plant height values of soybean were taller at lower water deficit levels ( $0 \%$ and $25 \%)$ than those grown under the relatively higher water deficit levels $(50 \%$ and $75 \%)$ in a greenhouse condition.

Regarding phosphorus effect, the tallest plant height was recorded from $46 \mathrm{~kg} \mathrm{P}_{2} \mathrm{O}_{5} \mathrm{ha}^{-1}(31.18 \mathrm{~cm})$ while plants treated with no $\mathrm{P}_{2} \mathrm{O}_{5}$ supply had the shortest plant height $(22.67 \mathrm{~cm})$ (Table 6).
The plant height was increased with increasing the levels of $\mathrm{P}_{2} \mathrm{O}_{5}$ up to $46 \mathrm{~kg} \mathrm{ha}^{-1}$ and then remained constant afterward. This result is in accordance with the findings of Imran et al. [36] and Imran et al. [37], who noted that the maximum plant height was recorded up to the optimum range of phosphorus application in mung bean.

Number of branches per plant: The main effects of irrigation regimes and phosphorus rates significantly $(\mathrm{P}<0.001)$ influenced the mean number of branches per plant. The $100 \%$ ETc recorded the highest branches number plant ${ }^{-1}$ (6.29) while 50\% ETc recorded the smallest (3.82) (Table 6). Similarly, Raza et al. [38] and Uddin et al. [31] reported that the number of branches plant ${ }^{-1}$ of mung bean decreased when the water stress was increased.

The highest number of branches plant ${ }^{-1}$ was observed on a plant treated with $46 \mathrm{~kg} \mathrm{P}_{2} \mathrm{O}_{5}$ ha $^{-1}$ (5.54) while the lowest was recorded at $0 \mathrm{~kg} \mathrm{P}_{2} \mathrm{O}_{5} \mathrm{ha}^{-1}$ (4.14) (Table 6). The increment in several branches plant ${ }^{-1}$ could be due to the importance of $\mathrm{P}$ for cell division and elongation activity, leading to the increase of plant height and number of branches, and consequently increased plant dry weight [39]. This result is in conformity with Parvez et al. [40] and Singh et al. [20] reported that increased levels of $\mathrm{P}_{2} \mathrm{O}_{5}$ increased the number of branches per plant of mung bean.

Shoot dry matter: Shoot dry matter showed highly significant $(\mathrm{P}<0.001)$ response to irrigation regimes and phosphorus rates. The highest (15.66 plant $^{-1}$ ) was at $100 \%$ ETc while the lowest (8.77g plant ${ }^{-1}$ ) was at $50 \%$ ETc (Table 6 ). This could be since water helps for cell enlargement and expansion because of turgor pressure and cell division which ultimately increase the growth of the plant. The similar observation has also been reported by Uddin et al. [31] in mung bean and Fening et al. [41] in forage legumes.

The highest shoot dry matter $\left(14 \mathrm{~g} \mathrm{plant}^{-1}\right)$ was recorded from $46 \mathrm{~kg}_{2} \mathrm{O}_{5}$ ha $^{-1}$ whereas the lowest was (10.31g plant ${ }^{-1}$ ) recorded from no supply of phosphorus (Table 6). Significantly higher (32.35\%) shoot dry matter was obtained from the application of $46 \mathrm{~kg} \mathrm{P}_{2} \mathrm{O}_{5}$ ha $^{-1}$ as compared to the control treatments. This increment in shoot dry matter with the addition of $\mathrm{P}$ fertilizer might be due to the supply of sufficient amount of $\mathrm{P}$ that resulted to an increase in a number of leaves plant ${ }^{-1}$, and leaf area, which in turn increased photosynthetic area, leading to higher assimilation and enhanced growth. This consequently increased dry matter accumulation and yield. An increased production of dry matter indicates the better utilization of nutrients along with better use of solar energy. This agrees with the research outcomes of Singh et al. [20] who observed that the maximum dry matter of mung bean was produced from the application of $45 \mathrm{~kg}_{2} \mathrm{O}_{5} /$ ha.

\section{Nodulation}

Number of nodules per plant: Number of nodules per plant was significantly $(\mathrm{P}<0.01)$ affected due to both the main and interaction effects of deficit irrigation and phosphorus rates. The maximum number of nodules plant ${ }^{-1}$ (25.5) was recorded from $100 \%$ ETc combined with $46 \mathrm{~kg} \mathrm{P}_{2} \mathrm{O}_{5}$ ha $^{-1}$ while the minimum number of nodules plant ${ }^{-1}$ (6.7) was recorded from $50 \%$ ETc combined 
with no $\mathrm{P}_{2} \mathrm{O}_{5}$ addition (Figure 1). Variation in nodule number had become larger and significant among irrigation regimes at higher rates of $\mathrm{P}_{2} \mathrm{O}_{5}$ application that included rates of 46 and $69 \mathrm{~kg} \mathrm{ha}^{-1}$. This increment in number of nodules due to the fact that adequate soil moisture and higher dose of $\mathrm{P}$ enhance the uptake of nutrients, and other numerous biochemical and enzymatic reactions in the soil which in turn hastened the growth of plants, stimulation of root development, initiation of nodule formation and eventually produce more number of nodules per plant. Sharma et al. [42] reported that the highest dose of phosphorus and the wettest regime of irrigation results in the highest availability and uptake of $\mathrm{P}$ by the plant.

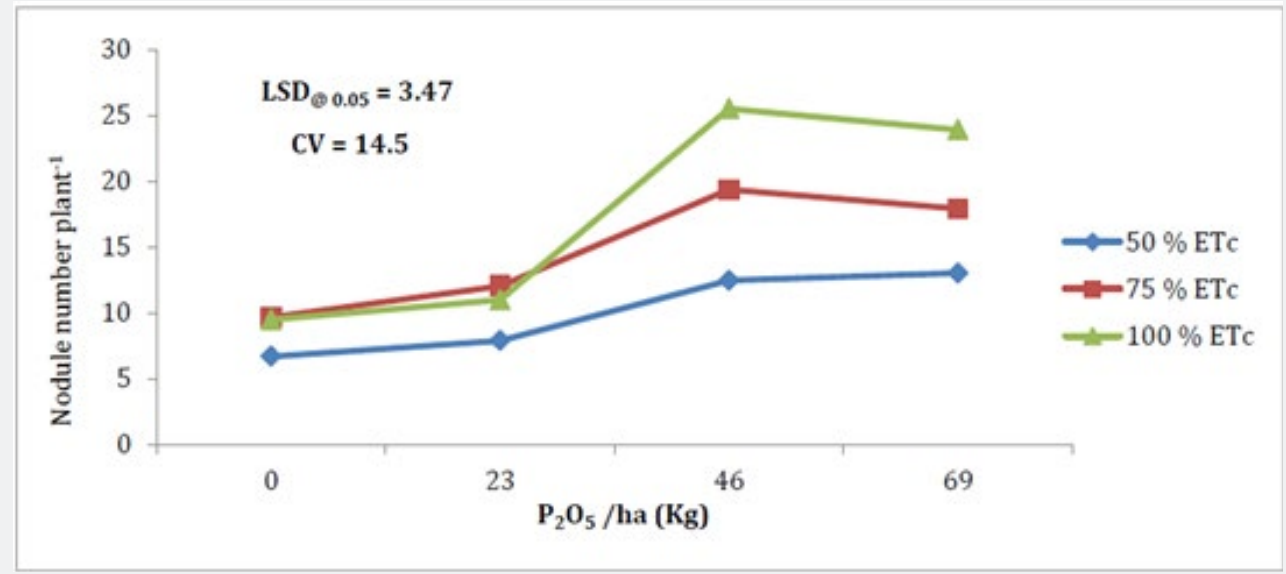

Figure 1: Interaction effects of irrigation levels and phosphorus rates on number of nodules plant ${ }^{-1}$.

Number of effective nodules per plant: The variability of effective number of nodules per plant was significantly $(\mathrm{P}<0.001)$ influenced by the main and interaction effects of deficit irrigation and phosphorus rates. Legume nodules having pink, red or dark red color centers are caused by the pigment leghemoglobin that controls oxygen flow to the rhizobia which are an indication for the effectiveness of the strain used and has a positive correlation with nitrogen fixed $[43,44]$. Whereas white and/or green nodule color, which indicated the ineffectiveness of the existing native rhizobium population in the soil.

The highest effective nodule numbers plant ${ }^{-1}$ (24.3) was recorded at $100 \%$ ETc combined with $46 \mathrm{~kg}_{2} \mathrm{O}_{5} \mathrm{ha}^{-1}$ whereas the lowest (6.4) was recorded at $50 \%$ ETc combined with control treatment (Figure 2). As the result showed the combination of $100 \%$ ETc and $46 \mathrm{~kg} \mathrm{P}_{2} \mathrm{O}_{5} \mathrm{ha}^{-1}$ had $73.6 \%$ higher effective nodule number plant $^{-1}$ than the combination of $50 \%$ ETc and control treatment (no fertilizer). This might be since adequate soil moisture and phosphorus in the soil enhances the root and microbial activities and facilitates aeration in the root zone of the plant which in turn increases the absorption and fixation of nutrient, and ultimately increases the effective number of nodules per plant.

Nodule dry weight: The obtained result showed that significant $(\mathrm{P}<0.01)$ effect of irrigation regimes, phosphorus rates and the interaction on nodule dry weight. The highest nodule dry weight $\left(0.27 \mathrm{~g} \mathrm{plant}^{-1}\right)$ was recorded at $100 \%$ ETc combined with $46 \mathrm{~kg} \mathrm{P}_{2} \mathrm{O}_{5}$ ha $^{-1}$ while the lowest $\left(0.08 \mathrm{~g}\right.$ plant $\left.{ }^{-1}\right)$ was at $50 \%$ ETc combined with control treatment (Figure 3). The reduction of nodule dry weight with the increase of water stress and phosphorus deficiency could be due to the limited growth and development as well as dry matter accumulation by the host plant. Nodule dry weight significantly and positively correlated with shoot dry matter $\left(r=0.79^{* * *}\right)$ and grain yield $\left(r=0.76^{* * *}\right)$ (Figure 4$)$.

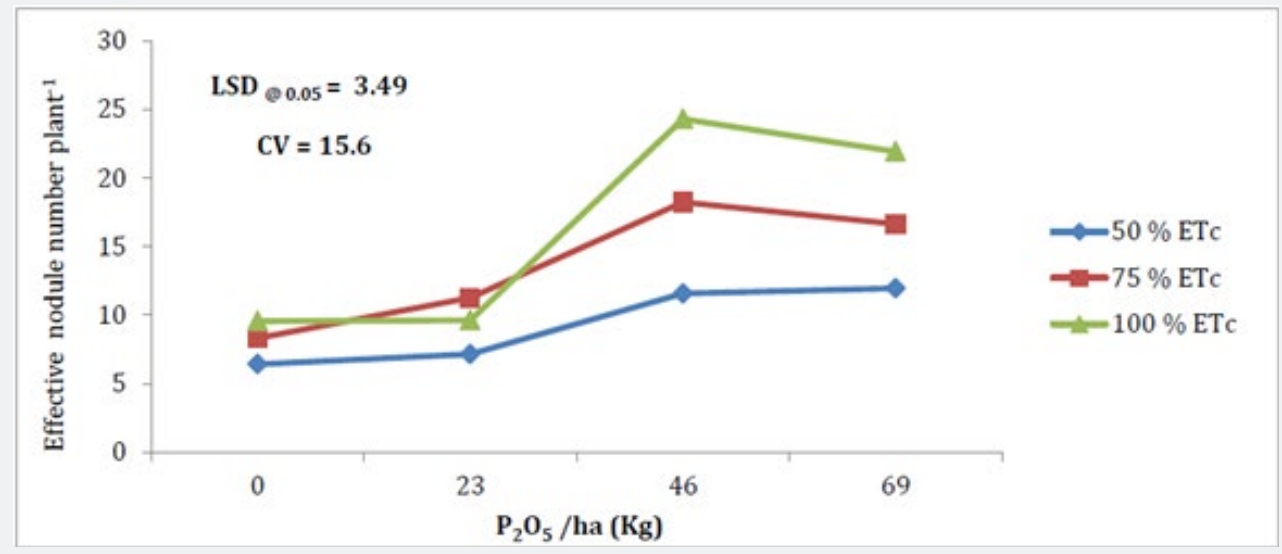

Figure 2: Interaction effect of irrigation levels and phosphorus rates on effective number of nodules plant ${ }^{-1}$. 


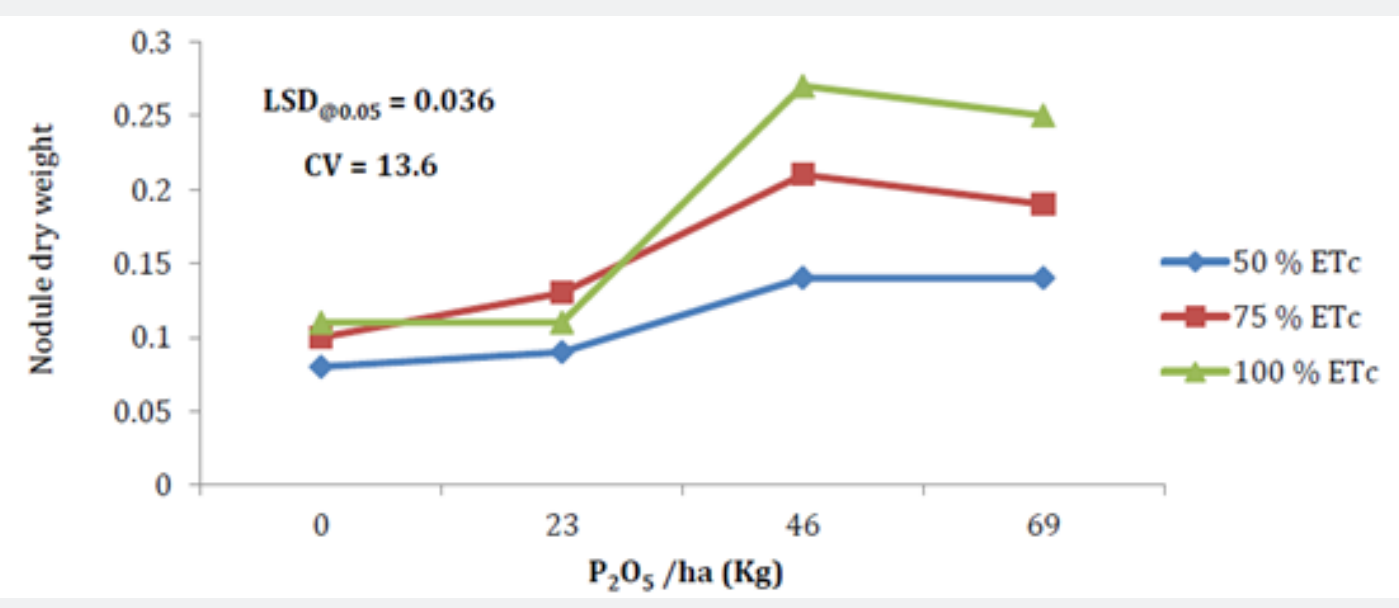

Figure 3: Interaction effects of irrigation levels and phosphorus rates on nodules dry weight (g).
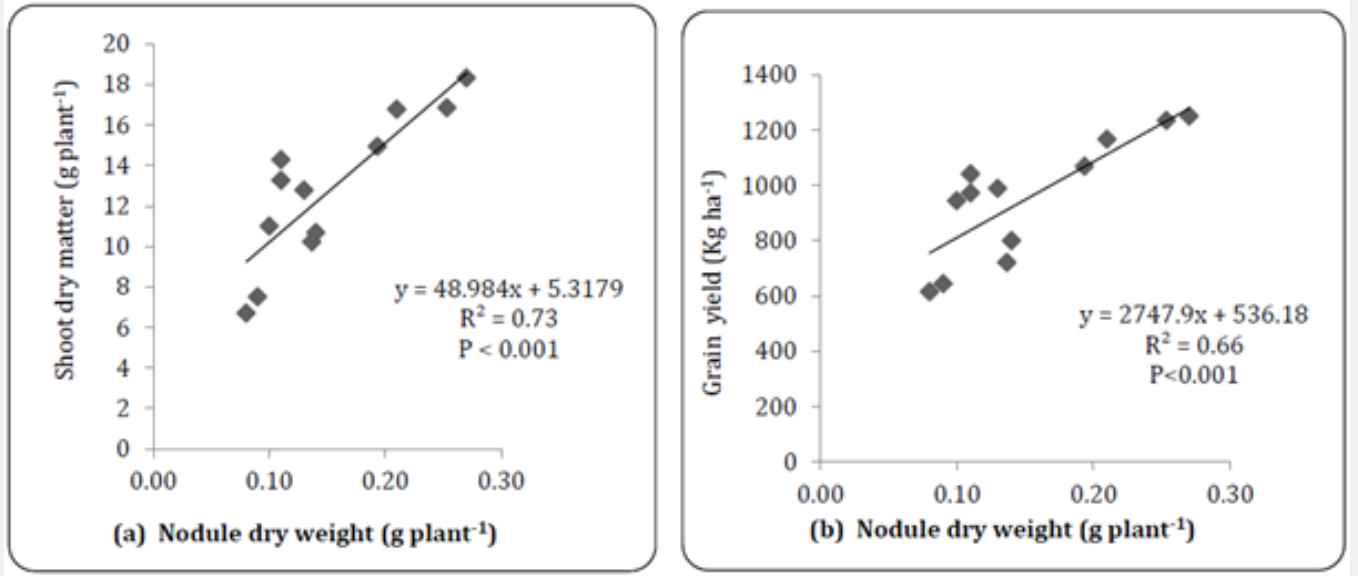

Figure 4: Correlation between (a) nodule dry weight and shoot dry matter, and (b) nodule dry weight and grain yield.

\section{Yield and yield components}

Pod length: Pod length plant ${ }^{-1}$ on mung bean plants was significantly $(\mathrm{P}<0.001)$ affected by only the deficit irrigation and phosphorus application. The $100 \%$ ETc irrigation level giving the longest pod length $(10.93 \mathrm{~cm})$ while the shortest pod length plant ${ }^{-1}$ $(9.27 \mathrm{~cm})$ was obtained under $50 \%$ ETc irrigation (Table 7).

The longest pod length $(10.72 \mathrm{~cm})$ was obtained from $46 \mathrm{~kg}$ $\mathrm{P}_{2} \mathrm{O}_{5}$ ha $^{-1}$ whereas the shortest pod length $(9.16 \mathrm{~cm})$ was obtained from control treatments. The similar observation has also been reported by Parvez et al. [40] in mung bean and Dereje [32] in haricot bean.

Number of pods per plant: The obtained result showed that number of pods per plant were significantly $(\mathrm{P}<0.001)$ influenced by variations in levels of irrigation and phosphorus rates but the interaction had non-significant effect. The 100\% ETc had produced the highest number (18.60) of pods per plant while $50 \%$ deficit (50\% ETc) the least number (10.52) of pods per plant (Table 7). The reduction in number of pods per plant might have been due to abortion and abscission of flowers and pods, incomplete fertilization, and limitation of dry matter partitioning to the reproductive sink under moisture stress. Although our results generally higher, similar observations have been made by Sisay et al. [21] and Sadeghipour [12] who reported that 12 pods/plant under optimal irrigation application while the 9.20 pods under $50 \%$ deficit irrigation throughout the growing season and 17.22 pods/plant under optimum irrigation, whereas 9.22 pods/plant when water stressed at the flowering stage respectively.

The greatest number of pods plant ${ }^{-1}$ (16.68) was obtained at P levels of $46 \mathrm{~kg} \mathrm{P}_{2} \mathrm{O}_{5}$ ha $^{-1}$ which was statistically at par with $69 \mathrm{~kg}$ $\mathrm{P}_{2} \mathrm{O}_{5} \mathrm{ha}^{-1}$, whereas the smallest number of pods plant ${ }^{-1}$ (11.48) was obtained in the control treatment (Table 7). The increment of number of pods plant ${ }^{-1}$ with increase in $\mathrm{P}$ application might be because $\mathrm{P}$ has a strong role in the reproductive growth of the crop in promoting flowering and pod formation. Similar observations have also been reported by Parvez et al. [40] and Rathore et al. [45] in mung bean and Girma et al. [46] and Tessema \& Alemayehu [29] in common bean. 
Number of seeds per pod: The number of seeds per pod were significantly $(\mathrm{P}<0.001)$ influenced by irrigation and phosphorus application. However, the interaction effect of irrigation and phosphorus was not significant. The maximum number of seeds/pod (11.68) was recorded at $100 \%$ ETc while the minimum number of seeds/pod (9.53) was recorded at 50\% ETc (Table 7). The 50\% deficit level gave the lowest number of seeds per pod that was reduced by $18.4 \%$ compared to the $100 \%$ ETc (control). The increment of the number of seeds per pod under optimal irrigation might be due to the presence of enough moisture, which is crucial on the photosynthetic surface area to produce assimilates and the production of assimilates that are ultimately needed to produce seeds. The reduction of number of seeds per pods due to the adverse effect of water deficit stress on meiosis and pollen fertility is observed in many cereals [47]. This result supported by Thomas et al. [30] and Merkebu [35] who found that the number of seeds per pod decreased consistently with increase in water deficit level on mung bean and soybean, respectively.

Table 7: Main effects of irrigation levels and phosphorus rates on pod length plant ${ }^{-1}$, No of pods plant ${ }^{-1}$, No of seeds pod ${ }^{-1}$ and hundred seed weight.

\begin{tabular}{|c|c|c|c|c|}
\hline Treatments & Pod Length Plant $^{-1}(\mathrm{~cm})$ & No of Pods Plant ${ }^{-1}$ & No of Seeds Pod ${ }^{-1}$ & Hundred Seed Weight (g) \\
\hline \multicolumn{5}{|c|}{ Irrigation Levels } \\
\hline $50 \%$ ETc & $9.27^{\mathrm{b}}$ & $10.52^{\mathrm{b}}$ & $9.53^{\mathrm{b}}$ & $5.92^{\mathrm{c}}$ \\
\hline $75 \%$ ETc & $9.82^{\mathrm{ab}}$ & $13.85^{\mathrm{ab}}$ & $10.43^{b}$ & $7.41^{\mathrm{b}}$ \\
\hline $100 \%$ ETc & $10.93^{\mathrm{a}}$ & $18.60^{\mathrm{a}}$ & $11.68^{\mathrm{a}}$ & $8.15^{\mathrm{a}}$ \\
\hline $\mathrm{LSD}_{0.05}$ & 1.19 & 5.11 & 1.21 & 0.32 \\
\hline \multicolumn{5}{|c|}{$P_{2} O_{5}\left(\mathrm{~kg} \mathrm{ha}^{-1}\right)$} \\
\hline 0 & $9.16^{c}$ & $11.48^{\mathrm{b}}$ & $9.71^{\mathrm{d}}$ & $6.67^{\mathrm{d}}$ \\
\hline 23 & $9.84^{\mathrm{b}}$ & $13.04^{\mathrm{b}}$ & $10.27^{c}$ & $7.03^{c}$ \\
\hline 46 & $10.72^{\mathrm{a}}$ & $16.68^{\mathrm{a}}$ & $11.36^{\mathrm{a}}$ & $7.63^{\mathrm{a}}$ \\
\hline 69 & $10.36^{\mathrm{a}}$ & $16.09^{\mathrm{a}}$ & $10.87^{\mathrm{b}}$ & $7.32^{\mathrm{b}}$ \\
\hline $\mathrm{LSD}_{0.05}$ & 0.5 & 1.79 & 0.47 & 0.23 \\
\hline $\mathrm{CV} \%$ & 5.73 & 12.59 & 4.5 & 3.3 \\
\hline
\end{tabular}

LSD = Least significant difference, CV = coefficient of variations, NS = non-significant. Means followed by the same letter within the column are not significantly different at $\mathrm{P}<0.05$.

The maximum number of seeds pod $^{-1}(11.36)$ were obtained at P levels of $46 \mathrm{~kg} \mathrm{P}_{2} \mathrm{O}_{5}$ ha $^{-1}$, whereas the minimum numbers of seeds $\operatorname{pod}^{-1}$ (9.71) were obtained in the control treatment (Table 7). This finding agrees with the findings of Parvez et al. [40], Singh et al. [20], and Tessema \& Alemayehu [30] who reported that number of seeds pod ${ }^{-1}$ increased with the increased phosphorus rates on mung bean and common bean, respectively.

Hundred seed weight: The weight of hundred seeds was significantly $(\mathrm{P}<0.001)$ influenced by irrigation and phosphorus application but the interaction had non-significant effect. The highest 100 seed weight $(8.15 \mathrm{~g})$ was recorded at optimal irrigation while the lowest value $(5.92 \mathrm{~g})$ was recorded at $50 \%$ deficit irrigation (Table 7). The $50 \%$ deficit irrigation level compared to the control, reduced hundred seed weight by $27.36 \%$ indicating that water deficit at this level produced relatively light seeds. Furthermore, seeds produced at $50 \%$ deficit levels were comparatively

Table 8: Main effects of irrigation levels and phosphorus rates on grain yield, biological yield, harvest index, crop water use efficiency and irrigation water use efficiency.

\begin{tabular}{|c|c|c|c|c|c|}
\hline Treatments & GY $\left(\mathbf{t ~ h a}^{-1}\right)$ & BY $\left(\mathbf{t ~ h a}^{-\mathbf{1}}\right)$ & HI (\%) & CWUE $\left(\mathbf{k g} / \mathbf{m}^{3}\right)$ & IWUE $\left(\mathbf{k g} / \mathbf{m}^{3}\right)$ \\
\hline \multicolumn{7}{|c|}{ Irrigation Levels } \\
\hline $50 \% \mathrm{ETc}$ & $0.695^{\mathrm{b}}$ & $3.416^{\mathrm{b}}$ & $20.34^{\mathrm{c}}$ & $0.41^{\mathrm{a}}$ & $0.28^{\mathrm{a}}$ \\
\hline $75 \% \mathrm{ETc}$ & $1.042^{\mathrm{a}}$ & $4.066^{\mathrm{a}}$ & $25.63^{\mathrm{b}}$ & $0.40^{\mathrm{a}}$ & $0.27^{\mathrm{a}}$ \\
\hline $100 \% \mathrm{ETc}$ & $1.124^{\mathrm{a}}$ & $3.967^{\mathrm{a}}$ & $28.34^{\mathrm{a}}$ & $0.33^{\mathrm{b}}$ & $0.22^{\mathrm{b}}$ \\
\hline $\mathrm{LSD}_{0.05}$ & 0.15 & 0.55 & 2.22 & 0.057 & 0.04 \\
\hline
\end{tabular}

smaller in size and were shriveled in their morphology. As reported by Tesfaye [48], the pod filling stage is sensitive to water deficit and water stress may lead to source limitation making the sink to accumulate less dry matter. In line with this, Merkebu [35] and Ghassemi-Golezani et al. [49] reported that reduced seed weight due to increase the water deficit levels of soybean and faba bean respectively.

The highest hundred seed weight $(7.63 \mathrm{~g})$ was obtained from $46 \mathrm{~kg} \mathrm{P}_{2} \mathrm{O}_{5} \mathrm{ha}^{-1}$, whereas the lowest hundred seed weight (6.67g) was recorded in the control treatment (Table 7). This result is supported by earlier studies of Mitra et al. [50] and Sadeghipour et al. [51] reported that increased number of pods per plant, number of seeds per pod, 1000 seeds weight and seed yield of mung bean with increased levels of phosphorus. Similarly, Dereje [32] observed that phosphorus application made significant differences in hundred seed weights of haricot bean.

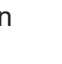




\section{Agricultural Research \& Technology: Open Access Journal}

\begin{tabular}{|c|c|c|c|c|c|}
\hline \multicolumn{6}{|c|}{$\mathrm{P}_{2} \mathrm{O}_{5}\left(\mathrm{~kg} \mathrm{ha}^{-1}\right)$} \\
\hline 0 & $0.844^{b}$ & $3.610^{\mathrm{b}}$ & $23.38^{b}$ & $0.33^{b}$ & $0.23^{b}$ \\
\hline 23 & $0.891^{b}$ & $3.760^{\mathrm{ab}}$ & $23.70^{\mathrm{b}}$ & $0.35^{\mathrm{b}}$ & $0.24^{\mathrm{b}}$ \\
\hline 46 & $1.072^{\mathrm{a}}$ & $3.985^{\mathrm{a}}$ & $26.90^{\mathrm{a}}$ & $0.42^{\mathrm{a}}$ & $0.29^{\mathrm{a}}$ \\
\hline 69 & $1.008^{\mathrm{a}}$ & $3.909^{\mathrm{a}}$ & $25.79^{a}$ & $0.39^{\mathrm{a}}$ & $0.27^{\mathrm{a}}$ \\
\hline $\mathrm{LSD}_{0.05}$ & 0.077 & 0.25 & 1.68 & 0.03 & 0.02 \\
\hline $\mathrm{CV} \%$ & 8.19 & 6.69 & 6.85 & 7.95 & 7.95 \\
\hline
\end{tabular}

$\mathrm{LSD}=$ Least significant difference, $\mathrm{CV}=$ coefficient of variations. Means followed by the same letter within the column are not significantly different at $\mathrm{P}<0.05$.

Grain Yield: The grain yield $\left(\mathrm{t} \mathrm{ha}^{-1}\right)$ significantly $(\mathrm{P}<0.001)$ response to irrigation levels and phosphorus rates but the interaction had not significant effect. The maximum grain yield $(1.124$ $\mathrm{t} \mathrm{ha}^{-1}$ ) was obtained at $100 \%$ ETc, whereas the lowest yield $(0.695$ $\mathrm{t}$ ha $^{-1}$ was obtained from $50 \%$ ETc (Table 8). The yield attained from $100 \%$ ETc was $38.2 \%$ greater than the yield attained from $50 \%$ ETc. There was no statistical difference between the yield under optimal irrigation and that of 75\% ETc irrigation. This result agrees with the finding of Sisay et al. [21] who reported that the $34 \%$ yield reduction at $50 \%$ deficit irrigation throughout the growing season as compared to the yield under optimum irrigation. Similarly, Malik et al. [52] and Thomas et al. [30] reported that water stress reduced plant growth and yield of mung bean.

The maximum grain yield $\left(1.072 \mathrm{t} \mathrm{ha}^{-1}\right)$ was obtained at applied P levels of $46 \mathrm{~kg} \mathrm{P}_{2} \mathrm{O}_{5}$ ha $^{-1}$ whereas the minimum grain yield $\left(0.844 \mathrm{t} \mathrm{ha}^{-1}\right)$ was recorded in the control treatment (Table 8). The average yield significantly increased with increasing levels of phosphorus up to $46 \mathrm{~kg}_{2} \mathrm{O}_{5} \mathrm{ha}^{-1}$. Increase in grain yield due to phosphorus application could be due to increase branching, fruiting, number of pods per plant, number of seeds per pod, and 100 seeds weight. Such increase in yield could also be due to improved root development, and translocation of photosynthates towards the sink development $[53,54]$. Similar results were reported by Singh et al. [20] that $\mathrm{P}$ application at the rate of $45 \mathrm{~kg} \mathrm{P}_{2} \mathrm{O}_{5}$ ha $^{-1}$ gave higher yield as compared to $30 \mathrm{~kg} \mathrm{P}_{2} \mathrm{O}_{5}$ ha $^{-1}, 15 \mathrm{~kg} \mathrm{P}_{2} \mathrm{O}_{5}$ ha $^{-1}$ and control plots in mung bean. Consistent with the results of this study, other researchers reported significant increases in the grain yield of mung bean in response to phosphorus application under field conditions $[17,28]$.

The grain yield showed significant and positive correlation with plant height $\left(\mathrm{r}=0.86^{* * *}\right)$, branches plant ${ }^{-1}\left(\mathrm{r}=0.81^{* * *}\right)$, pods plant $^{-1}\left(r=0.84^{* * *}\right)$, pod length plant ${ }^{-1}\left(r=0.68^{* * *}\right)$, seeds pod ${ }^{-1}$ $\left(\mathrm{r}=0.77^{* * *}\right)$, hundred seed weight $\left(\mathrm{r}=0.74^{* * *}\right)$, shoot dry matter $\left(\mathrm{r}=0.85^{* * *}\right)$, biological yield $\left(\mathrm{r}=0.84^{* * *}\right)$ and harvest index $(\mathrm{r}=$ $0.81^{* * *}$ ). This result is in accordance with the findings of Canci \& Toker [55] who reported that grain yield is significantly and positively correlated with the biological yield $(r=0.688)$, pods per plant $(r=0.682)$, plant height $(r=0.602)$, branches per plant $(r=$ $0.585)$, straw yield ( $r=581)$, grains per pod $(r=0.574)$, and pod number $(r=0.51)$ of mung bean.

Biological yield: The biological yield was significantly influenced by variation in levels of irrigation and phosphorus rates, but the interaction effect was not significant. The maximum biological yield (4.066 $\left.\mathrm{tha}^{-1}\right)$ was obtained from the $75 \%$ ETc irrigation application which had statistically at par with $100 \%$ ETc, whereas the minimum biological yield (3.416t ha $\left.{ }^{-1}\right)$ was gained from 50\% ETc irrigation application (Table 8). Similarly, Sadeghipour [12] who reported that increased total biomass of mung bean was responsive to the amount of irrigation water applied in both throughout the growth stages and at the specific growth stages.

The biological yield was significantly $(\mathrm{P}<0.05)$ influenced by phosphorus rates. The highest biological yield (3.985t ha-1) was obtained at applied P levels of $46 \mathrm{~kg} \mathrm{P}_{2} \mathrm{O}_{5}$ ha $^{-1}$, whereas the lowest biological yield (3.610t ha-1) was recorded in the control treatment (Table 8). However, there was no statistically significant difference among 23, 46 and $69 \mathrm{~kg} \mathrm{P}_{2} \mathrm{O}_{5}$ ha $^{-1}$ rates. The variation in biological yield of the crop between control treatment and $\mathrm{P}$ applied treatments could be due to the constructive effects of $\mathrm{P}$ in leaf area index, which may affect photosynthesis and photo-assimilate synthesis. The increases in biomass are the increase in P supply has been reported for mung bean [56], and for haricot bean [46,57]. Biological yield was significantly and positively associated with Plant height $\left(\mathrm{r}=0.70^{* * *}\right)$, no of branches/plant $\left(\mathrm{r}=0.59^{* *}\right)$ and no of pods per plant $\left(\mathrm{r}=0.67^{* * *}\right)$. Similarly, Canci \& Toker [55] who explained that the biological yield of mung bean was positively correlated with straw yield $(r=0.989)$, plant height $(r=0.834)$, kernels per pod $(r=0.690)$ and pods number $(r=0.479)$.

Harvest index: Harvest index $(\mathrm{HI})$ was significantly $(\mathrm{P}<0.01)$ affected by the main effects of irrigation levels and phosphorus rates but the interaction effect was not significant. The maximum harvest index (28.40) was obtained under 100\% ETc while the minimum harvest index (20.30) was obtained under 50\% ETc (Table 8). Harvest index of mung bean were reduced as a result of soil moisture stress has been reported for mung bean Hossain et al. [58] and Sisay et al. [21] and for soybean Merkebu [35].

The highest harvest index (26.67) was obtained at applied $P$ levels of $46 \mathrm{~kg} \mathrm{P}_{2} \mathrm{O}_{5}$ ha-1 $^{-1}$ whereas the lowest harvest index (23.21) was recorded in the control treatment (Table 8). However, there was no significant difference between control treatments and $23 \mathrm{~kg} \mathrm{P}_{2} \mathrm{O}_{5} \mathrm{ha}^{-1}$, and between 46 and $69 \mathrm{~kg} \mathrm{P}_{2} \mathrm{O}_{5}$ ha $^{-1}$. In line with this result, Amanullah et al. [28], Parvez et al. [40] and Singh et al. [20] who indicated that harvest index of mung bean increases in response to $\mathrm{P}$ application. 


\section{Water use efficiency}

Crop water use efficiency: The main effects of irrigation water levels and phosphorus rates significantly $(\mathrm{P}<0.001)$ influenced the mean values of CWUE but the interaction effect was non-significant. The maximum $\left(0.41 \mathrm{~kg} / \mathrm{m}^{3}\right)$ was obtained when $50 \%$ of the crop water requirement while the minimum $\left(0.33 \mathrm{~kg} / \mathrm{m}^{3}\right)$ was obtained from $100 \%$ ETc (Table 8). The plausible reason why water use efficiency increased under deficit irrigation water application may be attributed to reduced water loss through evaporation and wisely use irrigation water. This result is in conformity with Sisay et al. [21] who noted that the maximum water use efficiency of mung bean was gained when applied $50 \%$ of the crop water requirement throughout the entire seasons; the range between optimum irrigation and $50 \%$ deficit irrigation is from $0.413 \mathrm{~kg} / \mathrm{m}^{3}$ to $0.507 \mathrm{~kg} / \mathrm{m}^{3}$. Onder et al. [59] also reported that the maximum water use efficiency of cotton was obtained by applying $50 \%$ of the crop water requirement throughout the whole seasons.

The highest CWUE $\left(0.42 \mathrm{~kg} / \mathrm{m}^{3}\right)$ was obtained at applied $\mathrm{P}$ levels of $46 \mathrm{~kg} \mathrm{P}_{2} \mathrm{O}_{5}$ ha $^{-1}$, whereas the lowest CWUE $\left(0.33 \mathrm{~kg} / \mathrm{m}^{3}\right)$ was recorded in the control treatment (Table 8). This result is in conformity with the result of Dwangan et al. [60] who found that water use efficiency was increased with phosphorus application. On contrary, Singh et al. [20] and Singh [61] reported reduction of water use efficiency in response to phosphorus application which is due to higher proportionate increase in grain yield than consumptive use.

Irrigation water use efficiency: Only the main effects of irrigation levels and phosphorus rates on irrigation water use efficiency were significant $(\mathrm{P}<0.001)$. The highest $\left(0.28 \mathrm{~kg} / \mathrm{m}^{3}\right)$ was obtained when $50 \%$ ETc while the lowest $\left(0.22 \mathrm{~kg} / \mathrm{m}^{3}\right)$ was obtained when $100 \%$ ETc (Table 8). Similarly, Sisay et al. [21] also reported irrigation water use efficiency of mung bean were $0.248 \mathrm{~kg} / \mathrm{m}^{3}$ and $0.304 \mathrm{~kg} / \mathrm{m}^{3}$ under optimum and $50 \%$ deficit irrigation, respectively.

The irrigation water use efficiency was significantly influenced by phosphorus rates. The highest IWUE $\left(0.29 \mathrm{~kg} / \mathrm{m}^{3}\right)$ was obtained at applied P levels of $46 \mathrm{~kg} \mathrm{P}_{2} \mathrm{O}_{5} \mathrm{ha}^{-1}$ whereas the lowest IWUE $\left(0.23 \mathrm{~kg} / \mathrm{m}^{3}\right)$ was recorded in the control treatment (Table 8). However, there was no significant difference between no phosphorus and $23 \mathrm{~kg} \mathrm{P}_{2} \mathrm{O}_{5} \mathrm{ha}^{-1}$, and between 46 and $69 \mathrm{~kg} \mathrm{P}_{2} \mathrm{O}_{5}$ ha $^{-1}$.

Partial budget analysis: Partial budgeting is a method of organizing experimental data and information about the costs and benefits of various alternative treatments. The partial budget and marginal rate of return was calculated basis on CIMMYT [25]. The analysis of the marginal rate of return (MRR) for this experiment revealed that $75 \%$ and $100 \%$ ETc irrigation levels, and $46 \mathrm{~kg} \mathrm{P}_{2} \mathrm{O}_{5}$ $\mathrm{ha}^{-1}$ phosphorous application rates had given a marginal rate of return above the minimum acceptable rate (100\%). This indicated that farmers at the study area need to use $100 \%$ ETc irrigation water level and $46 \mathrm{~kg} \mathrm{P}_{2} \mathrm{O}_{5} \mathrm{ha}^{-1}$ application rate in order to maximize their profitability. However, due to the absence of significant yield difference between $100 \%$ and $75 \%$ ETc and in the interest of sustainable resource use, farmers can have profitable mung bean production by applying preferably $75 \%$ ETc and $46 \mathrm{~kg} \mathrm{P}_{2} \mathrm{O}_{5} \mathrm{ha}^{-1}$ (Table $9 \& 10$ ).

Table 9: Partial Budget and Marginal Analysis of deficit irrigation levels.

\begin{tabular}{|c|c|c|c|}
\hline \multirow{2}{*}{} & \multicolumn{3}{|c|}{ Deficit Irrigation (\% ETc) } \\
\cline { 2 - 4 } & $\mathbf{5 0}$ & $\mathbf{7 5}$ & $\mathbf{1 0 0}$ \\
\hline Average Yield $\left(\mathrm{kg} \mathrm{ha}^{-1}\right)$ & 695 & 1042 & 1124 \\
\hline Adjusted Yield $\left(\mathrm{kg} \mathrm{ha}^{-1}\right)$ & 625.5 & 937.8 & 1011.6 \\
\hline GFB ETB & 18765 & 28134 & 30348 \\
\hline $\begin{array}{c}\text { Labour Cost for Irrigation Application } \\
\text { ETB }\end{array}$ & 1000 & 1300 & 1500 \\
\hline Total Cost that Vary ETB ha-1 & 1000 & 1300 & 1500 \\
\hline Net Benefits ETB ha-1 & 17765 & 26834 & 28848 \\
\hline Marginal Cost (Birr ha-1) & - & 300 & 200 \\
\hline Marginal Net Benefit (Birr ha $\left.^{-1}\right)$ & - & 9069 & 2014 \\
\hline Marginal Rate of Return (\%) & - & 3023 & 1007 \\
\hline
\end{tabular}

Table 10: Partial budget and marginal analysis of different rates of phosphorus.

\begin{tabular}{|c|c|c|c|c|}
\hline & \multicolumn{4}{|c|}{$\operatorname{kg}_{2} \mathrm{O}_{5}$ ha $^{-1}$} \\
\hline & $\mathbf{0}$ & 23 & 46 & 69 \\
\hline Average Yield $\left(\mathrm{kg} \mathrm{ha}^{-1}\right)$ & 843.6 & 891.4 & 1071.8 & 1008 \\
\hline Adjusted Yield $\left(\mathrm{kg} \mathrm{ha}^{-1}\right)$ & 759.24 & 802.26 & 964.62 & 907.2 \\
\hline GFB ETB & 22777.2 & 24067.8 & 28938.6 & 27216 \\
\hline $\begin{array}{l}\text { Labour Cost for Fertilizer } \\
\text { application ETB }\end{array}$ & 0 & 200 & 200 & 200 \\
\hline Fertilizer Cost ETB ha ${ }^{-1}$ & 0 & 725 & 1450 & 2175 \\
\hline $\begin{array}{l}\text { Total Cost that Vary ETB } \\
\text { ha }^{-1}\end{array}$ & 0 & 925 & 1650 & 2375 \\
\hline Net Benefits ETB ha ${ }^{-1}$ & 22777.2 & 23142.8 & 27288.6 & $24841 \mathrm{D}$ \\
\hline Marginal Cost (Birr ha-1) & - & 925 & 725 & - \\
\hline $\begin{array}{l}\text { Marginal Net Benefit (Birr } \\
\text { ha }^{-1} \text { ) }\end{array}$ & - & 365.6 & 4145.8 & - \\
\hline $\begin{array}{c}\text { Marginal Rate of Return } \\
(\%)\end{array}$ & - & 39.5 & 571.8 & - \\
\hline
\end{tabular}

\section{Summary and Conclusion}

The results of this experiment showed that both the main effect of irrigation levels and phosphorus rates significantly $(\mathrm{P}<0.05)$ influenced the days to flowering, days to physiological maturity, plant height, number of branches per plant, shoot dry matter, pod length per plant, number of pods per plant, number of seeds per pod, hundred seed weight, grain yield, biological yield, harvest index, CWUE, IWUE and post-harvest soil phosphorus status. However, there were no significant interaction effects of irrigation levels and phosphorus rates on those parameters. The interaction effects of irrigation and phosphorus also significantly $(\mathrm{P}<0.01)$ influenced the total number of nodules per plant, effective number of nodules per plant and nodule dry weight.

The highest grain yield $\left(1.124 \mathrm{t} \mathrm{ha}^{-1}\right)$ was obtained from the application of irrigation water at $100 \%$ ETc but not statistically significant difference was showed with 75\% ETc irrigation level. 
However, the lowest grain yield $\left(0.695 \mathrm{tha}^{-1}\right)$ was obtained from $50 \%$ ETc irrigation water application. The highest grain yield (1.072t ha-1) was produced by the application of $46 \mathrm{~kg} \mathrm{P}_{2} \mathrm{O}_{5} \mathrm{ha}^{-1}$ while the lowest grain yield $\left(0.844 \mathrm{tha}^{-1}\right)$ was produced from control treatments. Correlation analysis indicated that grain yield significantly and positively correlated with all phenology, growth, yield and yield component parameters. The highest water use efficiency was obtained under 50\% ETc irrigation level which was statistically similar with 75\% ETc irrigation level. However, 100\% ETc irrigation level had significantly lower water use efficiency this implies that increase water use reduces efficiency. The highest water use efficiency was recorded from $46 \mathrm{~kg} \mathrm{P}_{2} \mathrm{O}_{5}$ ha $^{-1}$ which was statistically at par with $69 \mathrm{~kg} \mathrm{P}_{2} \mathrm{O}_{5} \mathrm{ha}^{-1}$.

The analysis of the marginal rate of return (MRR) at study area revealed that $75 \%$ and $100 \%$ ETc irrigation levels, and $46 \mathrm{~kg} \mathrm{P}_{2} \mathrm{O}_{5}$ $\mathrm{ha}^{-1}$ phosphorous application rates had given a marginal rate of return above the minimum acceptable rate (100\%). In general, Rasa (N-26) cultivars had given higher grain yield at 100\% ETc irrigation water which was statistically at par with that from $75 \%$ ETc irrigation water, and $46 \mathrm{~kg}_{2} \mathrm{O}_{5}$ ha $^{-1}$ phosphorus was applied.

Therefore, it can be concluded that, for the intention of sustainable water resource use and increase water use efficiency application of $75 \%$ ETc irrigation and $46 \mathrm{~kg} \mathrm{P}_{2} \mathrm{O}_{5}$ ha $^{-1}$ phosphorus may possibly be recommended for better mung bean production at the study area and areas with similar agroecology. Since this study was undertaken in single location and season using only a few levels of irrigation water it is important to repeat the study over different locations using additional levels of irrigation to come up with a conclusive recommendation.

\section{Acknowledgement}

I would like to acknowledge Ministry of Agriculture and Natural Resource for all the necessary and available facilities, equipments' and services delivered. Special thanks are forwarded for Alage ATVET College department of plant science staff members who visited and assisted me during the study.

\section{References}

1. Yagoob H, Yagoob M (2014) The effects of water deficit stress on protein yield of mung bean genotypes. Peak Journal of Agricultural Science 2(3): 30-35

2. Minh NP (2014) Different factors affecting to mung bean (Phaseolus aureus) production. International Journal of Multidisciplinary Research and Development 1(4): 105-110.

3. Somta P, Srinives P (2007) Genome research in mung bean (Vigna radiata L.) Wilczek) and black gram (V. mungo L.) Hepper). Science Asia 33(Suppl 1): 69-74.

4. Anwar F, Latif S, Sultana B, Ashraf M (2007) Chemical composition and antioxidant activity of seeds of different cultivars of mung bean. J Food Sci 72(7): S503-S510.

5. Hussain F, Malik AU, Haji MA, Malghani AL (2011) Growth and yield response of two cultivars of mung bean (Vigna radiata L.) to different potassium levels. The Journal of Animal \& Plant Sciences 21(3): 622-625

6. Asfaw Asrate, Fekadu Gurum, Fitsum Alemayehu, Yayis Rezene (2012) Analysis of multi-environment grain yield trials in mung bean (Vigna radiata L.) Wilczek) based on GGE bipot in Southern Ethiopia. Agr Sci Tech 14(2): 389-398.

7. CSA (Central Statistical Agency) (2017) Agricultural Sample Survey 2016/2017 (2009 E.C). Report on area and production of major crops. Statistical Bulletin 584. Addis Ababa, Ethiopia.

8. Rehman A, Khalil SK, Nigar S, Rehman S, Haq I, et al. (2009) Phenology, plant height and yield of mung bean varieties in response to planting date. Sarhad J Agri 25(2): 147-151.

9. Rahim MA, Mia AA, Mahmud F, Zeba N, Afrin KS (2010) Genetic variability, character association and genetic divergence in mung bean ( $\mathrm{Vi}$ gna radiate $\mathrm{L}$. Wilczek). POJ 3(1): 1-6.

10. Fitsum H, Makombe G, Namara RE, Awulachew SB (2009) Importance of irrigated agriculture to the Ethiopian economy: Capturing the direct net benefits of irrigation. International Water Management Institute (IWMI Research Report 128). Colombo, Sri Lanka.

11. Montazar A (2009) Assessing the global water productivity of some irrigation command areas in Iran. World Academy of Science, Engineering and Technology 33: 424-428.

12. Sadeghipour 0 (2008) Effect of withholding irrigation at different growth stages on yield and component of mung bean (Vagna radiata) Varieties. J Agr Env sci 4(5): 590-594.

13. Ranawake A, Dahanayaka N, Amarasingha U, Rodrigo W, Rodrigo U (2011) Effect of Water Stress on Growth and Yield of Mung bean (Vigna Radiata L). Tropical Agricultural Research \& Extension 14(4): 76-79.

14. Arain GN (2012) Crop manager agronomy center pivot irrigation system valley irrigation in Pakistan private limited.

15. Adetunji MT (1995) Equilibrium Phosphate Concentration as an estimate of Phosphate needs Maize in some Tropical Alfisols. Tropical Agriculture 72: 285-289.

16. Anetor MO, Akinrinde EA (2006) Differences in the liming potential of some fertilizer materials in a tropical acid alfisol. J Applied Sci 6: 16861691.

17. Ali MA, Abbas G, Ullah K, Aslam M (2010) Response of Mung bean (Vigna radiata) to Phosphatic Fertilizer under Arid Climate. The J Ani \& Pla Sci 20(2): 83-86.

18. Iqbal S, Khan H, Shaheen H (2012) Growth and yield responses of mung bean (Vigna radiata L.) to different levels of phosphorus application under different tillage systems. Int J Agric Sci 4(1): 22-27.

19. Kumar R, Singh YV, Singh S, Latare AM, Mishra PK, et al. (2012) Effect of phosphorus and sulphur nutrition on yield attributes yield of mung bean (Vigna radiata L.). Journal of Chemical and Pharmaceutical Research 4(5): 2571-2573.

20. Singh Ashok K, Singh A, Animesh S, Pravin K, Saurabh K (2014) Effect of Irrigations and Phosphorus Fertilization on Productivity, Water Use Efficiency, and Soil Health of Summer Mung bean (Vigna Radiata L.). The Ecoscan 8(1-2): 185-191.

21. Sisay Ambachew, Tena Alamirew, Assefa Melese (2014) Performance of mung bean under deficit irrigation application in the semi-arid highlands of Ethiopia. Agricultural Water Management 136: 68-74.

22. EARO (Ethiopian Agricultural research Organization) (2004) Released crop varieties and their recommended cultural practices. Progress report. Addis Ababa, Ethiopia.

23. Allen R, Pereira LA, Raes D, Smith M (1998) Crop Evapo-transpiration Irrigation and Drainage Paper. No. 56. FAO. Rome, Italy.

24. Yenus Ousman (2013) Effects of irrigation and nitrogen levels on bulb yield, nitrogen uptake and water use efficiency of shallot (Allium cepa var. ascalonicum baker). African Journal of Agricultural Research 8(37): 4637-4643.

25. CIMMYT (1988) From agronomic data to farmer recommendations: An 
economic training handbook. Econ. Programme, CIMMYT, Mexico, D.F. p. 86.

26. Al-suhaibani NA (2009) Influence of early water deficit on seed yield and quality of faba bean under arid environment of Saudi Arabia. American-Eurasian J Agric \& Environ Sci 5(5): 649-654.

27. Amanullah, Majidullah, Imran K, Hussain Z, Muhammad Kakar K (2014) Pheno-morphological traits of mung bean as influenced by phosphorous and Tillage under Irrigated and Un-irrigated Conditions. Pure Appl Bio 3(2): 55-59.

28. Amanullah, Majidullah, Asim M, Khalid N, Asad Ali, et al. (2016) Effect of tillage and phosphorus interaction on yield of mung bean (Vigna radiata L., Wilczek) with and without moisture stress condition. Int Sci Res J 72(2): 114-139.

29. Tessema Tesfaye, Alemayehu Balcha (2015) Effect of Phosphorus Application and Varieties on Grain Yield and Yield Components of Common Bean (Phaseolus vulgaris L.). Am J Pl Nutr Ferti Tech 5(3): 79-84.

30. Thomas M, Robertson J, Fukai S, Peoples MB (2004) The effect of timing and severity of water deficit on growth, development, yield accumulation and nitrogen fixation of mung bean. Field Crops Res 86(1): 67-80.

31. Uddin S, Shahnaj P, Awal M (2013) Department morpho-Physiological Aspects of Mung bean (Vigna Radiata L.) in Response to Water Stress. International Journal of Agricultural Science and Research 3(2): 137 148.

32. Dereje Shanka, Nigussie Dechassa, Setegn Gebeyehu (2015) Response of Common Bean Cultivars to Phosphorus Application in Boloso Sore and Sodo Zuria Districts, Southern Ethiopia. East African Journal of Sciences 9(1): 49-60.

33. Nkaa F, Nwokeocha O, Ihuoma O (2014) Effect of phosphorus fertilizer on growth and yield of cowpea (Vigna unguiculata). IOSR J Pharm Biol Sci 9(5): 74-82.

34. Rama Shanker (1994) Response of Fench bean (Phaseolus vulgaris L.) to various moisture regimes and nitrogen levels. M.Sc. (Ag.) thesis, Dept of Agronomy, NDUA and T Kumarganj, Faizabad, UP, India. p. 98.

35. Merkebu Getachew (2014) Influence of Soil Water Deficit and Phosphorus Application on Phosphorus Uptake and Yield of Soybean (Glycine $\max$ L.) at Dejen, North-West Ethiopia. Am J Plant Sci 5(13): 18891906.

36. Imran, Hussain I, Khattak I, Rrehman A, Ahamd F, et al. (2015) Roots nodulation, yield and yield contributing parameters of mung bean cultivars as influenced by different Phosphorous level in Swat Pakistan. Pure \& App Bio 4(4): 557-567.

37. Imran, Asad Ali Khan, Inamullah Inam, Fayaz Ahmad (2016) Yield and yield attributes of Mungbean (Vigna radiata L.) cultivars as affected by phosphorous levels under different tillage systems. Cogent Food \& Agriculture 2: 1-10.

38. Raza MH, Sadozai GU, Baloch MS, Khan EA, Din I, et al. (2012) Effect of Irrigation Levels on Growth and Yield of Mung bean. Paki J Nutr 11(10): 974-977.

39. Havlin L, Beaton L, Tisdale L, Nelson L (1999) Soil fertility and fertilizers; an introduction to nutrient management. ( $6^{\text {th }}$ edn $)$, Pearson education Inc. New Delhi, India. pp. 499.

40. Parvez M, Paul S, Sarka M (2013) Yield and yield contributing characters of mung bean as affected by variety and level of phosphorus. J Agr of Environ 7(1): 15-118.

41. Fening JO, Quansah C, Sarfo-Kantanka A (2009) Response of three forage legumes to soil moisture stress. Journal of Science and Technology 29(3): 24-30.

42. Sharma BM, Yadav JS, Rajput RK (1984) Effect of irrigation and phosphorus application on available phosphorus in soil and on grain yield of mung. Indian J Agron 29: 107-112.
43. Adjei MB, Quesenberry KH, Chambeiss CG (2002) Nitrogen fixation and inoculation of forage legumes. An electronic publication of Agronomy Department. University of Florida, USA, p. 1-5.

44. Bulter TJ, Evers G (2004) Inoculation, nodulation, nitrogen fixation and transfer. Texas cooperative extension (press). p. 1-4.

45. Rathore R, Khandwe R, Khandwe N, Singh P (1992) Effect of irrigation schedules, phosphorus levels and phosphate solubilizing organism on lentil yield. Lens 19: 7-19.

46. Girma Wolde, Yeshialem Melese, Tsegaye Babege (2017) Response of Haricot Bean (Phaseolus Vulgaris L.) to Lime Application and Rhizobium Inoculation on Nitosols at Bench-Maji Zone, Southwestern Ethiopia. J Plant Biol \& Soil Health 4(1): 5-10.

47. Saini HS, Westgate ME (2000) Reproductive development in grain crops during drought. Adv Agron 68: 59-95.

48. Tesfaye K (2004) Field Comparison of Resource Utilization and Productivity of Three Grain Legume Species under Water Stress. Ph.D. Dissertation, University of the Free State, Bloemfontein.

49. Ghassemi-Golezani K, Ghanehpoor S, Mohammadi-Nasab AD (2009) Effects of Water Limitation on Growth and Grain Filling of Faba Bean Cultivars. Journal of Food, Agriculture \& Environment 7(3-4): 442-447.

50. Mitra S, Rhattacharya SK, Datta M, Banik S (1999) Effect of variety, rock phosphate and phosphate solubilizing bacteria on growth and yield of green gram in acid soils of Tripura. Environmental \& Ecology 17(4): 926-930.

51. Sadeghipour 0, Monem R, Taiali A (2010) Production of Mung bean (Vigna radiata L.) as Affected by Nitrogen and Phosphorus Fertilizer Application. Journal of applied science 10(10): 843-847.

52. Malik Amjad, Fayyaz-Ul-Hassan, Abdul Waheed, Ghulam Qadir, Rehana Asghar (2006) Interactive effects of irrigation and phosphorus on green gram (Vigna radiata L.) Pakistan Journal Botany 38(4): 11191126.

53. Hussain A, Ali A, Khaliq T, Ahmad A, Aslam Z, et al. (2014) Growth, nodulation and yield components of mung bean (Vigna radiata) as affected by phosphorus in combination with rhizobium inoculation. Afr J Agric Res 9(30): 2319-2323.

54. Pal A, Kumar P, Singh RP, Kumar P (2014) Effect of different phosphorus levels on Urd Bean under custard apple based Agri-Horti system. J Agri Res 1(1): 30-34.

55. Canci H, Toker C (2014) Yield Components in Mung Bean [Vigna radiata (L.) Wilczek]. Turkish Journal of Field Crops 19(2): 258-261.

56. Khan M, Amir M, Safdar B, Ishtiaq T, Inamullah G (1999) Effect of Phosphorous on the Growth and Yield of Mungbean. Paki J Bio Sci 2(3): 667669.

57. Mesfin Kassa, Belay Yebo, Abera Habte (2014) The response of haricot bean (Phaseolus vulgaris L.) varieties to phosphorus levels on nitosols at Wolaita Zone, Ethiopia. Am J Plant Nutr Fertiliz Technol 4(1): 27-32.

58. Hossain BM, Wuluir RM, Noorul AH, Hossen AK (2010) Effect of Water Stress on Yield Attributes and Yield of Different Mung bean Genotypes. Int J Sustain Crop Prod 5(1): 19-24.

59. Onder D, Akiscan Y, Onder S, Mert M (2009) Effect of different irrigation water level on cotton yield and yield components. Afri J Biote 8(8): 1536-1544.

60. Dwangan MK, Pandey N, Tripathi RS (1992) Yield and water use efficiency of summer green gram (Phaseolus radiatus) as influenced by row spacing, irrigation schedule and phosphorus level. Indian J Agri 37: 587-588.

61. Singh JP, Karamanos RE, Srewenr JW (1988) The mechanism of phosphorus-induced zinc deficiency in bean (Phaseolus vulgaris L.). Can J Soil Sci 68(2): 345-358. 
This work is licensed under Creative Commons Attribution 4.0 License

DOI: 10.19080/ARTOAJ.2019.21.556167

\section{Your next submission with Juniper Publishers} will reach you the below assets

- Quality Editorial service

- Swift Peer Review

- Reprints availability

- E-prints Service

- Manuscript Podcast for convenient understanding

- Global attainment for your research

- Manuscript accessibility in different formats (Pdf, E-pub, Full Text, Audio)

- Unceasing customer service

Track the below URL for one-step submission https://juniperpublishers.com/online-submission.php 